\title{
Comparative Case Studies
}

\author{
Lesley Bartlett' \\ Frances Vavrus"
}

'University of Wisconsin-Madison, Madison - United States of America "University of Minnesota, Minneapolis - United States of America

\begin{abstract}
Comparative Case Studies. What is a case study and what is it good for? In this article, we review dominant approaches to case study research and point out their limitations. Next, we propose a new approach - the comparative case study approach - that attends simultaneously to global, national, and local dimensions of case-based research. We contend that new approaches are necessitated by conceptual shifts in the social sciences, specifically in relation to culture, context, space, place, and comparison itself.
\end{abstract}

Keywords: Case Study. Research Methods. Comparison. Context.

RESUMO - Estudos de Caso Comparado. O que é um estudo de caso e qual é sua utilidade? Neste artigo, revisamos os enfoques dominantes na pesquisa por estudo de caso e apontamos suas limitações. A seguir, propomos um novo enfoque - estudo de caso comparado - que atende simultaneamente às dimensões mundiais, nacionais e locais da pesquisa baseada em caso. Afirmamos que novas abordagens tornam-se necessárias devido a transformações conceituais nas ciências sociais, especificamente com relação à cultura, ao contexto, ao espaço, ao lugar e à própria comparação.

Palavras-chave: Estudo de Caso. Métodos de Pesquisa. Comparação. Contexto.

Educação \& Realidade, Porto Alegre, v. 42, n. 3, p. 899-918, July/Sept. 2017. 899 http://dx.doi.org/10.1590/2175-623668636 


\section{Introduction}

Case study methodology is widely used across multiple disciplines and fields. But what is a case, and what is a case study? In his introduction to the fascinating edited volume called What Is a Case?, Charles Ragin (1992, p. 1) argued that scholars use the word case "[...] with relatively little consideration of the theories and metatheories embedded in these terms or in the methods that use cases". Case is often defined as place. Researchers may use 'case' to mean one setting, place, or institution, or they may use 'case' for both the institution (or place or setting) and each person in it. We may also use case interchangeably with 'units of analysis', but this can be problematic because it does not sufficiently separate the categories we use to organize our data and the categories we construct based on our theoretical framework. In his essay, Ragin posed a series of provocative questions: What is the relationship between a case and a variable? Are there times when these mean the same thing? What is the difference between case-driven studies and variable-driven case studies? Is a case study constituted by empirical units (e.g., a state, or a hospital) or theoretical constructs? Finally, are cases discovered or developed over the course of conducting research, or are they "general and relatively external to conduct of research" (p. 8)? The answer to each of these questions has implications for how a researcher thinks about and uses case studies.

In this article, we offer an alterative conceptualization of case studies and the value of comparative case study research. We begin in the first section by discussing traditional conceptualizations of case studies. We pinpoint the limitations of traditional models of case studies, focusing on the frequently narrow notions of culture, context, and comparison. We then explain why we favor process-oriented approaches and how they are more appropriate for a comparative case study (CCS). We provide details about the key ideas that undergird our comparative case study approach, which include: focusing on the processes through which events unfold; reconceptualizing culture and context; a critical approach to power relations; and a revised understanding of the value of comparison (for a fuller treatment of these themes, see Bartlett and Vavrus, 2016).

\section{Traditional Case Study Approaches}

While a wide range of authors discuss case study methods, in this article we focus specifically on three who have been very influential in the United States. They include Robert Yin, a social scientist with a background in quantitative and experimental methods. Yin's book, Case Study Research (in its fifth edition at the time of our writing), has shaped research methods for decades. Yin (2014, p. 16) offered the following definition of a case study:

A case study is an empirical inquiry that investigates a contemporary phenomenon (the case) in-depth and within its real-world context, especially when the boundaries

900 Educação \& Realidade, Porto Alegre, v. 42, n. 3, p. 899-918, July/Sept. 2017. 
between phenomenon and context may not be clearly evident. In other words, you would want to do case study research because you want to understand a real world case and assume that such an understanding is likely to involve important contextual conditions pertinent to your case.

Yin emphasized the difficulty of distinguishing context and case, the importance of context, and a focus on contemporary events.

We also engage the work of Robert Stake, whose 1995 methods book was aptly titled The Art of Case Study Research. Stake emphasized a focus on meaning, stating that "[...] the ethnographic ethos of interpretive study, seeking out emic meanings held by the people within the case, is strong" (1995, p. 240). For Stake (1995, p. 2), researchers should view a case as "a bounded system" and inquire into it "as an object rather than a process". A case should be considered as "an integrated system" which "has a boundary and working parts" (p. 2). Cases, he said, are "holistic", "empirical", and "interpretive". Cases might be prized for their "intrinsic" value to better understand a specific case, or they may be "instrumental" if they serve to provide theoretical insights or reconsider generalizations (2003, p. 136-138). Stake celebrated the particular and the unique, and, in comparison to Yin and his quite structured case study approach, Stake promoted a flexible design that shifts in the course of research. In these ways, Stake's representation of case study methods is heavily interpretivist in orientation.

Finally, we consider the work of Sharan Merriam, whose 1998 publication, Qualitative research and case study applications in education, is widely cited in the education literature. Merriam (1998, p. xiii) described qualitative case study as "an intensive, holistic description and analysis of a bounded phenomenon such as a program, an institution, a person, a process, or a social unit". She asserted that "[...] if the phenomenon you are interested in studying is not intrinsically bounded, then it is not a case" (p. 27). For Merriam, cases are particularistic and descriptive; they focus on particular situations, events, or phenomena, and they yield a 'thick' description. While we would agree with some of what Stake, Yin, and Merriam promote, their approaches suffer from serious limitations, which we outline in the next section.

\section{Limitations of Traditional Approaches}

First, Yin, Stake, and Merriam conflate phenonemon and context, creating difficulties for understanding the 'case.' For Yin (2014, p. 17), case study was distinguished from experiments, which "separate a phenomenon from its context", and surveys, whose "ability to investigate the context is extremely limited". In this and other quotes, Yin seemed to define case as place and conflate case and context, stating that "the boundaries between phenomenon and context may not be clearly evident" (2014, p. 16). Stake, too, defined qualitative case studies as those that are holistic (considering the interrelationship of phenomenon and context), empirical, interpretive, and empathic (focused 
on meaning). Merriam similarly described a qualitative case study as "an intensive, holistic description and analysis of a bounded phenomenon..." (p. xiii). She later stated, "One of the assumptions underlying qualitative research is that reality is holistic, multidimensional, and ever-changing; it is not a single, fixed, objective phenomenon waiting to be discovered, observed, and measured as in quantitative research" (1998, p. 202). While we share these positive valuations of naturalistic inquiry in context, we are concerned that they promote a notion of "context as container", defining context as place. In other words, they frame the immediate temporal and place-based elements of the study are the only ones seen as relevant. As Ragin (1992) suggested, it demonstrates a fuzzy conflation of the place and the phenomenon, obfuscating the "theories and metatheories embedded in these terms" (p. 1).

This conflation of place and phenomenon relies on a misguided sense of holism. Holism is a concept linked to a traditional notion of culture and a functionalist theoretical stance. Classical ethnographies aimed to portray a whole way of life, which "implied a coherence of discrete cultures, a timeless 'ethnographic present'” (O'Reilly, 2009, p. 100). In its contemporary form, holism denotes a respect for context (and contextual validity). However, the claim to value holism is an effort to distinguish, but ultimately conflates, case and context (often defined as place), and it is premised upon a bounded view of culture. It also defines out of the realm of study far-flung factors and processes that may be immensely relevant for understanding how $a$ sense of boundedness is socially and historically produced. The notion of holism used in interpretive case studies is limited to thick description, to a dedication to "the particular", and to a reduced notion of context that does not attend to how processes, politics, and ideoscapes - the ideologies and other political images that circulate globally (Appadurai, 1996) - in other places or at other levels (or what we below call scales) impinge upon the case. Holism is surprisingly limited and rather blind to historical, social, and economic trends. Instead of this a priori bounding of the case to the 'particular,' we propose an iterative and contingent tracing of relevant factors, actors, and features.

Second, traditional case study authors insist on "bounding the case". For Yin (2011, p. 33-34), "bounding the case" is an essential step in the study. He wrote:

Once the general definition of the case has been established, other clarifications - sometimes called bounding the case - become important. If the unit of analysis is a small group, for instance, the persons to be included within the group must be distinguished from those who were outside of it... Similarly if the case is about the local services and a specific geographic area, you need to decide which services to cover.... [Clarify the boundaries of your case] with regard to the time covered by the case study; the relevant social group, organization, or geographic area; the type of evidence to be collected; and the priorities for data collection and analysis. 
To be fair, Yin did acknowledge that the research design might change over time (2011, p. 31-32); however, his emphasis on bounding is marked. Yin is not alone in his concern with "bounding" the case. Case study methodologist Creswell (2013) also suggested bounding by time and activity, and Miles and Huberman (1994) recommended bounding by definition and context. Each insists that bounding the case maintains a reasonable and feasible scope for the study. Stake (2003) adopted a functionalist notion of cases that relies on the sense of a case as a closed, bounded "system". He wrote that the case is a "bounded system" with:

[...] working parts; it is purposive; it often has a self. It is an integrated system....Its behavior is patterned. Coherence and sequence are prominent. It is common to recognize that certain features are within the system, within the boundaries of the case, and other features outside... are significant as context (Stake, 2003, p. 135; Stake, 1994, p. 237).

We argue that this imposed sense of a case as a "system" risks incorporating a functionalist vision of the case. Finally, like Yin and Stake, Merriam (1998, p. 27) was concerned with bounding the case. She wrote:

The single most defining characteristic of case study research lies in delimiting the object of study, the case. Smith's (1978) notion of the case as a bounded system comes closest to my understanding of what defines this type of research [....] [T]he case is a thing, a single entity, a unit around which there are boundaries [...] If the phenomenon you are interested in studying is not intrinsically bounded, it is not a case.

Merriam's view appears to be shaped by Miles and Huberman's (1994) understanding of "the case as a phenomenon of some sort occurring in a bounded context" (cited in Merriam, 1998, p. 27). This focus on bounding is distinct from our spatially - and relationally - informed understanding of context and our processual notion of culture.

We find this notion of bounding the case from the outset to be problematic. It aligns more with a neo-positivist design, which predefines variables and hypothesizes relationships, than it does with the iterative, processual designs more common in qualitative work. We contend that boundaries are not found; they are made by social actors, including by researchers, whose demarcations can often seem quite arbitrary and can have the effect of sealing off the case hermetically from other places, times, and influences. As we will explain further below, $a$ priori efforts to "bound the case" rely on limited notions of context and comparison.

Third, traditional approaches to case study research understate the value of case studies in social science research. For example, Yin (2009) declared three types of case studies: exploratory (collecting data and looking for patterns), descriptive (considering possible theories to 
frame the study and questions), and explanatory (explaining the how or why of the topic or population studied). Of these, we feel only an explanatory case rises to the level of significance expected of most social science research. Cases that are merely descriptive or exploratory are rarely given much credence. For Stake (2003, p. 136-138), "intrinsic" cases offer us a chance to better understand a specific case, while "instrumental" cases generate theoretical insights or prompt us to reconsider generalizations. Similarly, Merriam defined three types of cases (particularistic, descriptive, and heuristic, meant to increase understanding of the case and discovery of new meaning) and three purposes for them (descriptive, interpretive, and evaluative) (1998, p. 30). These descriptions largely remain limited to the particularistic and descriptive, declaring a reduced aspiration for greater theoretical import. The traditional view that case study research is often exploratory or descriptive denigrates it as an approach to meaningful scholarship.

Fourth, traditional approaches do not robustly defend the generalizability of case study findings. Yin promoted a distinct notion of generalizability for single case studies. He averred that "case studies, like experiments, are generalizable to theoretical propositions and not to populations or universes" (Yin, 2011, p. 21). Generalization, he said, can be a lesson learned or hypothesis applicable to other situations (2011). Yin warned against efforts to use single case studies for statistical generalization, as is common in quantitative studies (2011). We agree with his views of generalizing through theory; however, we worry that his conflation of phenomenon, context, and case limits the aspiration to generate theory or insights that will generalize to other cases. In contrast, Stake affirmed "understanding of the case rather than generalization beyond" (1994, p. 236), and he suggested that "the end result regularly presents something unique" (1994, p. 238). While we eschew a neo-positivist notion of generalizability through statistics, we would certainly not wish to forsake a more appropriate understanding of how qualitative work generalizes through the generation of theoretical insights that transfer to other cases. Indeed, some argue that the question of generalizability is one of the main misunderstandings of case studies: Flyvbjerg (2011) asserted that "the case study is ideal for generalizing using the type of test that Karl Popper called 'falsification", wherein "if just one observation does not fit with the proposition, it is considered not valid generally and must therefore be either revised or rejected" (2011, p. 305). We assert that, beyond falsification, cases generate rich theoretical insights that transfer to other times and places.

Fifth, we diverge from traditional approaches to case studies over the value of comparison. When addressing comparison, Yin urged replication to achieve external validity. Indeed, Yin considered replication to be the primary value of designs that include multiple case studies. $\mathrm{He}$ encouraged readers to "consider multiple cases as one would consider multiple experiments - that is, to follow a 'replication' design" by selecting cases that are expected to either produce similar results or produce different results for a predictable reason (2014, p. 57). Yin praised a tight, 
structured design for case studies and, in so doing, promoted concepts and approaches that are more appropriate for variance-oriented studies than the processual approach we advocate.

In his early work, Stake was circumspect about the value of comparison. Because he valued the particular elements of each case, Stake warned that "direct comparison diminishes the opportunity to learn from" the case (1994, p. 240). He continued: "I see comparison as an epistemological function competing with learning about and from the particular case. Comparison is a powerful conceptual mechanism, fixing attention upon the few attributes being compared and obscuring other knowledge about the case" (1994, p. 242). Stake felt that comparison prompted the decomposition of cases into variables. He contrasted comparison to thick description, and he stated that comparison downplays "uniqueness and complexities" (2003, p. 148-149).

In a later publication, Stake took a more sanguine view of comparison, acknowledging the value of the multiple case study. He described the multiple case study as "a special effort to examine something having lots of cases, parts, or members.... We seek to understand better how this whole... [or] 'quintain,' operates in different situations. The unique life of the case is interesting for what it can reveal about the quintain" (2006, p. vi). The quintain, then, is what is being sought across cases. Unfortunately, the concept as presented by Stake remains rather confusing. At some moments, Stake referred to the quintain as a whole that is greater than the sum of its parts. It appears to be an ideal type that is reached inductively through review of cases. Yet, in his 2006 book, the quintain also appears to be something like the least common denominator, or the themes that are adequately present across the cases. Thus, for Stake, the comparison of multiple case studies illuminates some larger phenomenon as well as how context shapes social life.

Our comparative case study heuristic would agree with Stake about the value of multiple cases. While the notion of 'quintain' is a bit obscure, we would happily substitute 'phenomenon,' or possibly stretch the idea to include 'policy.' However, as described further in the next section, we encourage comparison across three axes: a horizontal look that not only contrasts one case with another, but also traces social actors, documents, or other influences across these cases; a vertical comparison of influences at different levels, from the international to the national to regional and local scales; and a transversal comparison over time.

Traditional approaches to case study research have had a farranging impact on research in numerous fields, including the fields of education and policy studies in which we primarily work. However, we have noted some of their shortcomings. In sum, we question the conflation of phenomenon and context, and we critique their limited notion of context. In addition, we question the need to "bound" the case, a priori, in any definitive sense; instead, we promote careful, evolving, iterative attention to the contours of the research design and how boundaries perceived by participants come to be meaningful. We insist on gener- 
alizability through the generation of theoretical insights. Finally, we argue that there is much more potential for comparative case studies beyond the logic of replication proposed by Yin or the vague discussion of 'quintain' offered by Stake.

\title{
Process-Oriented Approaches and the Comparative Case Study Approach
}

As we have already hinted, the comparative case study approach diverges from established approaches in several important ways. To begin, it adopts what Maxwell called a process orientation. Process approaches "tend to see the world in terms of people, situations, events, and the processes that connect these; explanation is based on an analysis of how some situations and events influence others" (2013, p. 29). They "tend to ask how $x$ plays a role in causing $y$, what the process is that connects $x$ and $y$ " (2013, p. 31$)$.

Thus, the process-oriented comparison inherent to our notion of comparative case studies insists on an emergent design, one hallmark of qualitative research. As Becker (2009, p. 548) wrote, qualitative researchers:

\begin{abstract}
[...] don't fully specify methods, theory, or data when they begin their research. They start out with ideas, orienting perspectives, or even specific hypotheses, but once they begin, they investigate new leads; apply useful theoretical ideas to the (sometimes unexpected) evidence they gather; and, in other ways, conduct a systematic and rigorous scientific investigation. Each interview and each day's observations produce ideas tested against relevant data. Not fully pre-specifying these ideas and procedures, as well as being ready to change them when their findings require it, are not flaws, but rather two of the great strengths of qualitative research [....].
\end{abstract}

Because qualitative studies are emergent, researchers have to make explicit what Heath and Street (2008, p. 56) called "decision rules", or decisions about how to focus or expand the study. These should be noted in one's fieldnotes, and could be reproduced as a sort of "audit trail” (e.g., Lincoln; Guba 1985). The need for an emergent design is in conflict with the constant admonition in the traditional case study literature to "bound" the case. With this more process-oriented understanding in mind, we should be aware that some studies may be more pre-structured than others; the degree of flexibility will depend on the study's aims, the researcher's motivations, skills, and interests, and the available time and resources, among other things.

The CCS approach does not start with a bounded case. The effort to "bound" a case relies on a problematic notion of culture, place, and community; it also, quite inappropriately, defines out of the realm of study factors that may well be very relevant, such as historical circumstances that date back decades or more. Comparative case studies resist

906 Educação \& Realidade, Porto Alegre, v. 42, n. 3, p. 899-918, July/Sept. 2017. 
the holism of many traditional case studies, which stubbornly refuse to distinguish phenomenon from context, often defined implicitly as place. It is essential to divorce the phenomenon of interest from the context in order to gain analytical purchase. As Geertz (1973, p. 22) famously explained, "The locus of the study is not the object of study". At the same time, even while including multiple sites and cases, comparative case studies seek not to flatten the cases by ignoring valuable contextual information or imposing concepts or categories taken from one site onto another (Van der Veer, 2016). They seek to disrupt dichotomies, static categories, and taken-for-granted notions of what is going on (Heath; Street, 2008).

Instead of this a priori bounding of the case, the CCS approach features an iterative and contingent tracing of relevant factors, actors, and features (see Bartlett; Vavrus 2016). The approach is aimed at exploring the historical and contemporary processes that have produced a sense of shared place, purpose, or identity. For example, a study might compare how non-governmental organizations (NGOs) are operating in a particular region of a country and also contrast their interpretations of a policy to those of the NGO directors in the capital or to the NGOs' donors in another country. This is a quite different conceptualization of replication design as promoted by Yin and the need for tightly-bounded units of analysis that it implies. However, writing about how processes unfold in unpredictable ways across space and time often proves to be more challenging than resorting back to descriptions of multiple cases juxtaposed with one another.

Another feature of the CCS approach is that it aims to understand and incorporate, at least partially, the perspectives of social actors in the study. This is common to most qualitative research, especially ethnography and ethnographically-oriented studies. As Willis and Trondman stated, ethnography (and, we would add, other qualitative methods) are "a family of methods involving direct and sustained social contact with agents and of richly writing up the encounter, respecting, recording, representing at least partly in its own terms the irreducibility of human experience" (Willis; Trondman, 2000, p. 394, emphasis ours).

The CCS approach is also informed by a critical theoretical stance. By critical, we mean that the approach is guided by critical theory and its concerns and assumptions regarding power and inequality. Drawing upon Marxist, feminist, and critical race theory, among others, critical theory aims to critique inequality and change in society; it studies the cultural production of structures, processes, and practices of power, exploitation, and agency; and it reveals how common-sense, hegemonic notions about the social world maintain disparities of various sorts ${ }^{1}$.

Attention to power and inequality is central to the CCS approach.

In addition to these features of the CCS approach, we have developed it as a way to 'unbound' culture while still seeking to conduct rich descriptions of the phenomenon of interest to the researcher. Traditional approaches to case study work tend to rely on a homeostatic notion of culture as bounded and unchanging, like a set of rules. But major so- 
ciological work propelled the notion of culture from "a set of rules" to something more akin to principles or understandings that people used to "make sense" (Garfinkel, 1984; 2002) or develop a "feel for the game" (Bourdieu, 1990). Furthermore, scholars averred that what is important is not cultural difference per se, but when and how cultural difference is made consequential - e.g., when difference is cast as deficit or disability (e.g., McDermott; Varenne, 1995). Further, culture must be considered in relation to economic, political, and social phenomena; as anthropologist Sherry Ortner (1999, p. 9) averred, "the point is not that there is no longer anything we would call 'culture,' but that interpretive analysis of social groups should be situated within and, as it were, beneath larger analyses of social and political events and processes". Contemporary notions of culture focus on "practice or performance and hence emphasize the process of making meaning over the meanings themselves" (Anderson-Levitt, 2012, p. 443). Today, anthropologically-informed scholarship generally treats culture as an ever-changing, active, productive process of sense-making in concert with others (Erickson, 2011). Contests over meaning and practice are influenced by power relations, including direct imposition and, more commonly, the cultural production of "common sense" notions of social order.

There are important implications of this shift in conceptualizations of culture for case study research. While case studies frequently include a focus on meaning, this has sometimes been conceptualized as 'discovering' the meaning of a particular term or idea among members of 'a' culture or sub-culture, such as the meaning of style, respect, or success for working-class youth in Detroit or hedge fund managers in New York City. In contrast to this sense of (static) culture within a (bounded) group, the understanding of culture that undergirds the CCS approach provides strong justification for the importance of examining processes of sense-making as they develop over time, in distinct settings, in relation to systems of power and inequality, and in increasingly interconnected conversation with actors who do not sit physically within the circle drawn around the traditional case. The CCS heuristic warns against static and essentializing notions of culture, recommends attention to cultural repertoires and contestation, and emphasizes the need to consider power relations within a single institution or community and across communities, states, and nations. It also suggests that researchers pay particular attention to language, discourse, texts, and institutions as important social and policy actors. Finally, it insists on attention to social interactions, which may or may not transpire in person. This insight begs a consideration of context, another key term we consider central to CCS research.

The comparative case study heuristic draws upon a radical rethinking of context, another concept that is much-cited and yet ill-defined in case study research. In common parlance, context is often used to indicate the physical setting of people's actions. The importance exerted by context is one of the primary reasons for selecting a case study approach to research. To represent this aspect, some scholars refer to

908 Educação \& Realidade, Porto Alegre, v. 42, n. 3, p. 899-918, July/Sept. 2017. 
contextual or ecological validity. These terms originated in psychological studies to indicate "[...] the extent to which the environment experienced by the subjects in a scientific investigation has the properties it is supposed or assumed to have by the experimenter" (Bronfenbrenner, 1977, p. 516). Since that time, among sociocultural scholars, the term has come to suggest the importance of maintaining the integrity of realworld situations rather than studying a phenomenon in laboratory contexts. The concept offers an implicit critique of the effort to generalize by stripping away the particular. As Geertz wrote, "No one lives in the world in general. Everyone, even the exiled, the drifting, the diasporic, or the perpetually moving, lives in some confined and limited stretch of it - 'the world around here'” (Geertz, 1996, p. 262).

This point, we fully agree, is quite important. However, scholars continue to rely on a rather static, confined, and deterministic sense of context. No 'place' is unaffected by history and politics; any specific location is influenced by economic, political, and social processes well beyond its physical and temporal boundaries. As scholars Leander and Sheehy have argued, "context... has been overdetermined in its meaning by a seemingly natural interpretation of material setting or place" (2004, p. 3).

We contend that settings are constituted by social activities and social interactions (Duranti; Goodwin, 1992; Dyson; Genishi, 2005). Indeed, for those who draw upon activity theory, activity itself is the context - made up of actors, their objectives, their actions, and the artifacts they engage, each with their relevant histories (see, e.g., Cole, 1996; Engestrom, 1987; Engestrom et al., 1999). In this view, context is not a container for activity; it is the activity. Engaging a notion of culture as strategic and symbolic "sense making", we can see activities as purposeful efforts to respond to uncertainty in how to move forward. This way of thinking about context is also enhanced by Bourdieu's concept of "field", a symbolic arena in which agents are relatively positioned based on the (arbitrary, socially constructed, and open to negotiation) rules of the field, the agent's symbolic capital, and the agent's habitus (Bourdieu; Wacquant, 1992). We also embrace the idea of "fuzzy fields", which Nadai and Maeder (2005) described as "social worlds [...] formed by sets of common or joint activities or concerns bound together by a network of communications", wherein "sets of actors [are] focused on a common concern and [act] on the basis of a minimal working consensus" (2005). They continued, stating that "[...] identifying adequate sites, which add up to an ethnographic field, requires a theoretical clarification of the object of study first. Such a theoretical framework can then serve as a compass for the search of a field" (2005). That object of study is what we call the phenomenon of interest. In short, context is made; it is relational and spatial (see also Gupta; Ferguson, 1997).

Our notion of context also attends to power relations and the critical theories of place and space put forward by critical geographers and anthropologists. Doreen Massey $(1991 ; 1994 ; 2005)$ argued explicitly against the romantic idea that a place has a single, essential iden- 
tity based on a limited history of territory. In this view, place becomes a static, dead object. She critiqued this desire for fixity and boundedness:

Instead then, of thinking of places as areas with boundaries around, they can be imagined as articulated moments in networks of social relations and understandings, but where a large proportion of those relations, experiences and understandings are constructed on a far larger scale than what we happen to define for that moment as the place itself, whether that be a street, or a region or even a continent. And this in turn allows a sense of place which is extroverted, which includes a consciousness of its links with the wider world, which integrates in a positive way the global and the local (Massey, 1991, p. 28).

So-called local contexts, she argues, are quite heterogeneous and produced from the intersection of social, economic, and cultural relations linked to various scales.

Further, rethinking the production of and interconnections across sites reveals the sociocultural production of inequality. As Gupta and Ferguson (1992, p. 8) wrote, "The presumption that spaces are autonomous has enabled the power of topography to conceal successfully the topography of power". They asserted the importance of examining historically the processes by which local sites with different patterns of social relations came into being, rather than treating them as primordial places:

[...] taking a preexisting, localized 'community' as a given starting point... fails to examine sufficiently the processes (such as the structures of feeling that pervade the imagining of community) that go into the construction of space as place or locality in the first instance. In other words, instead of assuming the autonomy of the primeval community, we need to examine how it was formed as a community out of the interconnected space that always already existed (1997, p. 36; emphasis in original; see also Appadurai, 1999).

Gupta and Ferguson interrogated the all-too-common, apolitical and ahistorical term "community", and they insisted on a historical and processual approach (see also Vavrus, 2015). Not only are sites not autonomous - they are influenced by actions well beyond the local context and the current moment, and thus the idea of "bounding" them, which others argue is the hallmark of case study research, is an illusion. The 'unbounding' we call for in comparative case study research requires attention to the processes mentioned above. It also requires attention to scale. Scale is often used to distinguish local, regional, national, and global levels, though critical geographers have argued forcefully against the tendency to conceptualize these as distinct and unrelated. As Bruno Latour (2005, p. 177) stated, "the macro is neither 'above' nor 'below' the interactions, but added to them as another of their connections". In CCS research, one would pay close attention to how actions at different scales mutually influence one another. Middleton (2014) made 
this point succinctly: "To make social relations their objects of inquiry, researchers must adopt a multi-scalar focus and engage in multilevelled analysis. They must identify relations of proximity and distance, tracing relational links between near and far" (p. 18). These relations are critical to understanding how topographies of power are formed through the concatenation of multi-scalar political-economic forces that act upon the social imaginary to produce towns, neighborhoods, and villages out of previously non-demarcated space, and to bestow privileges upon some of them but not others.

This reconceptualization of context using spatial theory has important implications for case study work. It encourages us to attend very carefully to the social relations and networks that constitute the most relevant context in one's research and how these relations and networks have formed and shifted over time. Context is not a primordial or autonomous place; it is constituted by social interactions, political processes, and economic developments across scales and across time. Rethinking context steers us away from "bounding" a study a priori and, instead, makes the project one of identifying the historical and contemporary networks of actors, institutions, and policies that produce some sense of a bounded place for specific purposes. This inversion of the case study research process has important implications for comparison.

Finally, we argue that traditional case study approaches miss a major opportunity by not integrating comparison more centrally into their work. Our processual approach to comparison considers strings of relevant events and actors; it eschews staid notions of culture or context to consider those processes across space and time; and it constantly compares what is happening in one locale with what has happened in other places and historical moments. These forms of comparison are what we call horizontal, vertical, and transversal comparisons. What we aim for with our comparative case study approach is akin to what anthropologist Ulf Hannerz dubbed "studying through" (2006, p. 24). The horizontal axis compares how similar policies or phenomena unfold in distinct locations that are socially produced (Massey, 2005) and "complexly connected" (Tsing, 2005, p. 6). The vertical axis insists on simultaneous attention to and across scales (see also Bray; Thomas, 1995; Nespor, 2004, 1997). The transversal comparison historically situates the processes or relations under consideration.

\section{An Example of a Comparative Case Study}

An extended example of the axes of the comparative case study approach may be helpful at this juncture (for more examples, see Vavrus; Bartlett 2009, Bartlett; Vavrus 2016). Figure 1 represents a study we conducted with American and Tanzanian colleagues regarding the impact on Tanzanian teachers' practice of the global push toward learner-centered pedagogy (LCP), an approach to teaching in which students are actively engaged in meaningful and constructive learning in the classroom as opposed to listening to lectures and memorizing factual infor- 
mation (Vavrus; Bartlett, 2013). During the past few decades, LCP has been heavily promoted by international education and development organizations for various reasons, including its assumed benefits for cognitive growth, self-efficacy and empowerment, and democratization and the development of civil society (Schweisfurth, 2013). Since the mid 2000s, it has also been partially adopted by the Tanzanian government in its education policies and curricula.

\section{Figure 1 - Comparative Case Study Approach to Learner Centered Pedagogy in Tanzania}

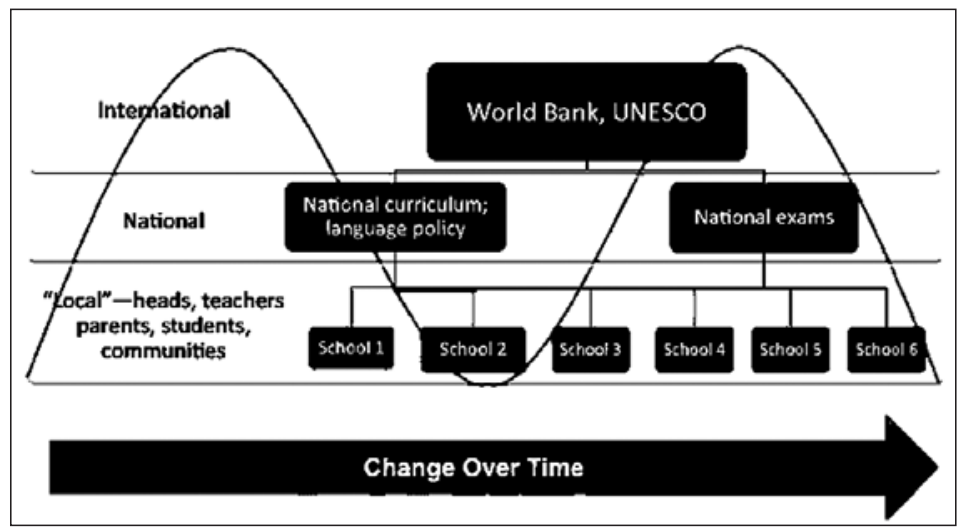

Illustrating the transversal axis, our study examined the ways in which LCP, a specific approach to teaching and learning popularized in the temporal and cultural context of the United States and the U.K. in the 1970s (Cuban, 1993; Ravitch, 1983), has been taken up, simplified, and spread globally. In that process, learner-centered pedagogy diffused very particular understandings of teaching and learning that rely upon culturally-specific notions of individualism, competition, cooperation, and authority and presume certain material conditions in schools and classrooms (see also Vavrus; Bartlett, 2012). Emphasizing change over time, we examined how the government of Tanzania has incorporated this perspective on teaching and learning into its education policies over the past 50 years. We used discourse analysis to trace the gradual incorporation of global ways of framing learning in national educational policies, beginning in the Education for All era of the 1990s.

A careful vertical analysis across scales is also important to the type of case study approach we propose. We emphasize the importance of examining policy formation and appropriation across micro-, meso-, and macro-levels. In Teaching in Tension, we documented consequential tensions that influenced the appropriation of learner-centered pedagogy. External donor funding supported Tanzanian curricular projects, which incorporated heavy doses of LCP (Bartlett; Vavrus, 2014). Around this time, donors, and especially the World Bank, also emphasized the importance of rigorous, standardized testing to measure educational quality and hold teachers accountable, leading to a significant 
contradiction when assessment specialists within the National Examination Council of Tanzania continued to devise high-stakes exams that captured rote memorization more than critical thinking. Because the tests had serious consequences for student advancement to secondary school and college, for teachers who may receive "motivation" money if their students perform well, and for schools (especially private schools) whose existence may depend on the high scores that attract new families and their tuition fees, the tests paradoxically encouraged methods that emphasize the memorization of factual information rather than learner-centered pedagogical approaches. This tendency was compounded by the breadth of the exams, which cover four years of information for seven or more subjects, making the acquisition of both core knowledge and higher-order thinking skills a great challenge. Thus, the curricular and assessment arms of the Ministry of Education and Vocational Training were in conflict, and actors located in international and national organizations had a great influence over the policies and curricular materials available to educators.

The larger study also made use of horizontal comparisons across six high schools in two adjacent regions in Tanzania to demonstrate the significant impact of transnational institutions and social movements on the material conditions of local schools and on the organizational dynamics within them. For instance, teachers at the school funded by an American non-profit organization enjoyed extensive professional development in learner-centered pedagogy, a life skills program for students, a sizable library with materials for developing inquiry-based projects, and relative material wealth as reflected in the availability of books, handouts, paper, photocopiers, and Internet access. These factors influenced the shape and tenor of the appropriation of LCP at that school, as observed by the research team and reported by its teachers. In contrast, the Catholic and Anglican schools, affiliated with powerful and quite hierarchical transnational institutions, presented a markedly different context within which to develop the more egalitarian relations between teachers and students that are implicit in LCP. For example, one teacher at a Catholic school complained that there were constraints on teachers organizing debates among students on topics of concern and interest to students, such as prostitution or HIV/AIDS. In religiously-affiliated schools, teachers' appropriations of the educational policies promoted by international institutions and embedded in national curricula were heavily influenced by religious notions of propriety, including gender norms.

More broadly, the horizontal comparison across these six high schools demonstrated how different material and ideological contexts affected the appropriation of learner-centered pedagogy within one country. According to the Tanzanian teachers who participated in the study, LCP is simply more difficult to implement in schools with overcrowded classrooms, few books to share among many students, limited poster board for making teaching aids, and even notebook paper to enhance group or pair work. (Vavrus; Bartlett, 2013). 
Finally, a horizontal comparison reminds us that policy is also made locally, and that teachers are key actors in educational policy appropriation: they interpret, negotiate, and revise policies on assessment, curriculum content, pedagogical methods, and language of instruction in the classroom (see, e.g., Menken; García, 2010). Our study, for instance, compared how teachers at six secondary schools struggled to implement a competency-based curriculum when the high-stakes, national exams continued to emphasize the recall of facts. Further, the project documented how teachers creatively enacted language policy, influenced by their own biographies as language learners as well as the social and material conditions in their schools and surrounding communities. Officially, at the time, secondary school teachers were required to teach and assess in English; however, this policy interfered with the implementation of learner-centered pedagogy because the latter demands greater English oral fluency in the language than many students (and quite a few teachers) possess (see Webb; Mkongo, 2013). Teachers commented frequently on the contradictory pressures created for them by the language, curricular, and assessment policies.

It should be clear from this example that the three axes of a comparative case study are mutually imbricated. For example, in comparing horizontally across schools and the teachers in them, we considered individual teachers' biographies; in comparing vertically, we looked at how the relationship between international donors and the Tanzanian state differentially affected local schools; and, running through the entire project was the transversal axis of learner-centered pedagogy and how its growing prominence in Tanzanian education policy over time has shaped teachers' biographies and has been shaped by donor-state relationships. Though we extricate the axes for purposes of explaining and illustrating them, it is essential to note the extent to which they can and do overlap (for more on each axis and how they complement one another, see Bartlett; Vavrus 2016).

\section{Conclusion}

In this article, we examined and critiqued traditional models of case study research. We problematized the notion of boundedness, in particular, and we also reconsidered notions of context and culture as they are used in the traditional case study literature. We argued that context should not be defined as place or location, but it should rather be conceptualized as something spatial and relational. We also explained why we eschew a static, bounded notion of culture in favor of a view of culture as an on-going, contested production. These notions are consequential for how we conceptualize case studies and comparison.

The Comparative Case Study Approach promotes a model of multi-sited fieldwork that studies through and across sites and scales. It encourages simultaneous and overlapping attention to three axes of comparsion: horizontal, which compares how similar policies or phenomena unfold in locations that are connected and socially produced; 
vertical, which traces phenomena across scales; and horizontal, which traces phenomena and cases across time. This revisioning has the potential to strengthen and enhance case study research in our field.

Received on October 05, 2016 Approved on December 08, 2016

\section{Note}

1 It is important to distinguish our use of critical from two other uses that appear in the case study literature. Patton (1990, p. 174) denominated critical cases as "those that can make a point quite dramatically or are, for some reason, particularly important in the scheme of things". Critical, for Patton, denoted a somewhat typical case - "if it happens there, it will happen anywhere". In this sense, a "critical" case has strategic importance in relation to the problem, allowing generalization, or (in contrast) providing for falsification by showing that general claims are invalid for this case (and, potentially, similar cases). A second notion of the term, what is called "critical incident case study", considers the factors, variables, or behaviors that are "critical to the success or failure of an activity or event and associated outcomes" (p. 247). With its focus on events, the method considers the "causal antecedents of an event and those critical actions or inactions taken by actors or agents that contributed to the event's or outcome's occurrence" (p. 247).

\section{References}

ANDERSON-LEVITT, Kathryn M. Complicating the concept of culture. Comparative Education, Wales, v. 48, p. 441-454, 4 May 2012.

APPADURAI, Arjun. Modernity at Large: cultural dimensions of globalization. Minneapolis: University of Minnesota Press, 1996.

APPADURAI, Arjun. Globalization and the research imagination. International Social Science Journal, v. 51, n. 160, p. 229-238, Jun. 1999.

BECKER, Howard. How to find out how to do qualitative research. International Journal of Communication, Los Angeles v. 3, p. 545-553, 2009.

BOURDIEU, Pierre. In Other Words: Essays towards a reflexive sociology. Stanford: Stanford University Press, 1990.

BOURDIEU, Pierre; WACQUANT, Loic. An Invitation to Reflexive Sociology. Chicago: University of Chicago Press, 1992.

BRONFENBRENNER, Urie. Toward an experimental ecology of human development. American Psychologist, Washington, v. 32, n. 7, 513-531, Jul. 1977.

COLE, Michael. Culture in Mind. Cambridge, MA: Harvard University Press, 1996.

CRESWELL, John. Research Design: qualitative, quantitative, and mixed methods approaches. Thousand Oaks, CA: Sage, 2013.

CUBAN, Larry. How Teachers Taught: constancy and change in American classrooms, 1890-1990. New York: Teachers College Press, 1993.

DURANTI, Alessandro; GOODWIN, Carlos. Rethinking Context: language as an interactive phenomenon. London: Cambridge University Press, 1992.

DYSON, Anne Haas; GENISHI, Celia. On the Case: approaches to language and literacy research. New York: Teachers College Press, 2005. 
ENGESTRÖM, Yrjo. Learning by Expanding: An activity-theoretical approach to developmental research. Helsinki: Orienta-Konsultit, 1987.

ENGESTRÖM, Yrjo; MIETTINEN, Reijo; PUNAMÄKI, Raija-Leena (Eds.). Perspectives on Activity Theory. Cambridge, UK: Cambridge University Press, 1999.

ERICKSON, Frederick. Culture. In: LEVINSON, Bradley; POLLOCK, Mica (Eds.). A Companion to the Anthropology of Education. West Sussex, UK: Wiley-Blackwell, 2011. P. 25-33.

FLYVBERG, Bent. Case study. In: DENZIN, Norman; LINCOLN, Yvonna (Eds.). The Handbook of Qualitative Research. 4 ed. Thousand Oaks, CA: Sage, 2011. P. 301-316.

GARFINKEL, Harold. Studies in Ethnomethodology. Cambridge, UK: Polity Press, 1984.

GARFINKEL, Harold. Ethnomethodology's Program: working out Durkheim's aphorism. Lanham, MD: Rowman \& Littleford, 2002.

GEERTZ, Clifford. The Interpretation of Cultures. New York: Basic Books, 1973. GEERTZ, Clifford. Afterword. In: FELD, Steven; BASSO, Keith (Eds.). Senses of Place. Santa Fe, NM: School of American Research Press, 1996. P. 259-262.

GUPTA, Akhil; FERGUSON, James. Beyond 'culture': space, identity, and the politics of difference. Cultural Anthropology, United States, v. 7, p. 6-23, Feb. 1922.

GUPTA, Akhil; FERGUSON, James. Culture, power, place: Ethnography at the end of an era. In: GUPTA, Akhil; FERGUSON, James (Eds.). Culture, Power, Place: explorations in critical anthropology. Durham, NC: Duke University Press, 1997. P. 1-32.

HANNERZ, Ulf. Studying down, up, sideways, through, backwards, forwards, away and at home: Reflections on the field worries of an expansive discipline. In: COLEMAN, Simon; COLLINS, Peter (Eds.). Locating the Field: space, place and context in anthropology. Oxford, UK: Berg, 2006. P. 23-41.

HEATH, Shirley Brice; STREET, Brian. On Ethnography: approaches to language and literacy research. New York: Teachers College Press, 2008.

LATOUR, Bruno. Reassembling the Social: an introduction to actor-network theory. Oxford: Oxford University Press, 2005.

LEANDER, Kevin; SHEEHY, Margaret (Eds.). Spatializing Literacy Research and Practice. New York: Peter Lang, 2004.

LESLEY, Bartlett; VAVRUS, Frances. Rethinking Case Study Research. New York: Routledge, 2016.

LESLEY, Bartlett; VAVRUS, Frances. Transversing the vertical case study: A methodological approach to studies of educational policy as practice. Anthropology \& Education Quarterly, United States, v. 45, n. 2, p. 131-147, Jun. 2014.

LINCOLN, Yvonna; GUBA, Egon. Naturalistic Inquiry. Beverly Hills, CA: Sage, 1985.

MARK, Bray; THOMAS, Murray. Levels of comparison in educational studies: Different insights from different literatures and the value of multilevel analyses. Harvard Educational Review, Massachusetts, v. 65, n. 3, p. 472-491, 1995.

MASSEY, Doreen. A global sense of place. Marxism Today, v. 38, p. 24-29, Jun. 1991.

MASSEY, Doreen. Space, Place, and Gender. Malden, MA: Polity Press, 1994.

916 Educação \& Realidade, Porto Alegre, v. 42, n. 3, p. 899-918, July/Sept. 2017. 
MASSEY, Doreen. For space. London: Sage, 2005.

MAXWELL, Joseph. Qualitative Research Design: an interactive approach. Thousand Oaks, CA: Sage, 2013.

MCDERMOTT, Ray; VARENNE, Hervé. Culture as disability. Anthropology \& Education Quarterly, v. 26, n. 3, p. 324-348, Sep. 1995.

MENKEN, Kate; GARCÍA, Ofelia. (Eds.). Negotiating Language Education Policies: educators as policymakers. New York, NY: Routledge, 2010.

MERRIAM, Sharan. Qualitative Research and Case Study Applications in Education. San Francisco: Jossey-Bass, 1998.

MIDDLETON, Sue. Henri Lefebvre and Education: space, history, theory. New York: Routledge, 2014.

MILES, Matthew; HUBERMAN, Michael. Qualitative Data Analysis: an expanded sourcebook. Thousand Oaks, CA: Sage, 1994.

NADAI, Eva; MAEDER, Christoph. Fuzzy fields: Multi-sited ethnography in sociological research. Forum Qualitative Sozialforschung / Forum: Qualitative Social Research, v. 6, n. 3, Sep. 2005. Disponible at: <http://www.qualitativeresearch.net/index.php/fqs/article/view/22/47> Accessed on: 25 Abr. 2016.

NESPOR, Jan. Tangled up in School. Mahwah, NJ: Lawrence Earlbaum Associates, 1997

NESPOR, Jan. Educational scale-making. Pedagogy, Culture \& Society, v. 12, n. 3, p. 309-326, 19 Dec. 2004.

O’REILLY, Karen. Key Concepts in Ethnography. Thousand Oaks, CA: Sage, 2009.

ORTNER, Sherry (Eds.). The Fate of "Culture": geertz and beyond. Cambridge: Harvard University Press, 1999.

RAGIN, Charles. Introduction: Cases of "what is a case?" In: RAGIN, Charles; BECKER, Howard (Eds.). What is a Case? Exploring the foundations of social inquiry. New York: Cambridge University Press, 1992. P. 1-17.

RAVITCH, Diane. The Troubled Crusade: american education, 1945-1980. New York: Basic Books, 1983.

SCHWEISFURTH, Michele. Learner-Centred Education in International Perspective: whose pedagogy for whose development? New York: Routledge, 2013.

STAKE, Robert. Case studies. In: DENZIN, Norman; LINCOLN, Yvonna (Eds.). Handbook of Qualitative Research. Thousand Oaks, CA: Sage, 1994. P. 236-247. STAKE, Robert. The Art of Case Study Research. Thousand Oaks, CA: Sage, 1995. STAKE, Robert. Case studies. In: DENZIN, Norman; LINCOLN, Yvonna (Eds.). Strategies of Qualitative Inquiry. 2 ed. Thousand Oaks, CA: Sage, 2003. P. 134164.

STAKE, Robert. Multiple Case Study Analysis. New York: The Guilford Press, 2006.

TSING, Anna. Friction: an ethnography of global connections. Princeton: Princeton University Press, 2005.

VAN DER VEER, Peter. The Value of Comparison. Durham: Duke University Press, 2016.

VAVRUS, Frances. Topographies of power: A critical historical geography of schooling in Tanzania. Comparative Education, v. 52, n. 2, p. 136-156, 1 Dec. 2015.

Educação \& Realidade, Porto Alegre, v. 42, n. 3, p. 899-918, July/Sept. 2017. 
VAVRUS, Frances; BARTLETT, Lesley. Comparatively knowing: Making a case for the vertical case study. Current Issues in Comparative Education, v. 8, p. 95-103, 2006.

VAVRUS, Frances; BARTLETT, Lesley. Critical Approaches to Comparative Education: Vertical case studies from Africa, Europe, the Middle East, and the Americas. New York: Palgrave Macmillan, 2009.

VAVRUS, Frances; BARTLETT, Lesley. Comparative pedagogies and epistemological diversity: Social and material contexts of teaching in Tanzania. Comparative Education Review, v. 56, n. 4, p. 634-658, 2012.

VAVRUS, Frances; BARTLETT, Lesley. Teaching in Tension: International pedagogies, national policies, and teachers' practices in Tanzania. Rotterdam: Sense Publishers, 2013.

WEBB, Tamara; MKONGO, Sarah. (2013). Classroom discourse. In: VAVRUS, Frances; BARTLETT, Lesley (Eds.). Teaching in Tension: International pedagogies, national policies, and teachers' practices in Tanzania. Rotterdam: Sense Publishers, 2013. P. 149-168.

WILLIS, Paul; TRONDMAN, Mats. Manifesto for ethnography. Ethnography, London, v. 1, p. 5-16. 2000.

YIN, Robert. Case Study Research: design and methods. 4 ed. Thousand Oaks, CA: Sage, 2009.

YIN, Robert. Applications of Case Study Research. Thousand Oaks, CA: Sage, 2011.

YIN, Robert. Case Study Research: design and methods. 5 ed. Thousand Oaks, CA: Sage, 2014.

Lesley Bartlett is a Professor in Educational Policy Studies and a faculty affiliate in Anthropology. An anthropologist by training who works in the field of International and Comparative Education, Professor Bartlett does research in literacy studies (including multilingual literacies), migration, and educator professional development.

E-mail: lesley.bartlett@wisc.edu

Frances Vavrus is Associate Professor and Coordinator of the Program in Comparative and International Development Education at the University of Minnesota, where she also holds the title of McKnight Presidential Fellow E-mail: vavru003@umn.edu 